\title{
ESL Teachers' Acting Agentively Through Job Crafting
}

\author{
Mari Haneda \\ Penn State University \\ mxh79@psu.edu \\ Brandon Sherman \\ Indiana University Purdue University at Indianapolis \\ shermanb@iu.edu
}

\begin{abstract}
Worldwide, countries strive for effective ways to educate migrant children, and the United States is no exception. In this context, this qualitative study examines how a group of ESL teachers in U.S. elementary schools acted agentively and redesigned their work through job crafting (Wrzesniewskum \& Dutton, 2001) so as to provide optimal support for English learners. Key findings indicate that, despite institutional constraints, teachers found ways to organize their work to align their practices with their educational goals. In some cases, they were able to negotiate with key school personnel to reconfigure their instructional practices, and in others they created multiple advocacy roles beyond the classroom. Based on our findings, we suggest that, in preparing ESL teachers, attention needs to be paid not only to pedagogy but also to the wider scope of their roles as advocates who navigate the micro-politics of school organization.
\end{abstract}

KEYWORDS: Job Crafting, School Contexts, Teacher Agency, ESL, Language Teacher Education

This is the author's manuscript of the article published in final edited form as:

Haneda, M., \& Sherman, B. (2018). ESL Teachers' Acting Agentively Through Job Crafting. Journal of Language, Identity \& Education, 17(6), 402-415. https://doi.org/10.1080/15348458.2018.1498340 


\section{ESL Teachers' Acting Agentively Through Job Crafting}

As a result of war, persecution or famine, many families have migrated to safer and more prosperous countries where their children can be educated to become able to participate fully in the life of their host countries. First, though, many of these migrant children have to learn a new language and unfamiliar sociocultural norms before they can benefit from their schooling in the host country (Janta \& Harte, 2013; Ruiz Soto, Hooker, \& Baltova, 2015). This, in turn, puts a considerable strain on the education systems of the host countries. In the United States, notwithstanding the recognition of the need for grade-level teachers to be adequately equipped to instruct these newcomers, there is a tendency for the responsibility for the education of English learners $^{1}$ (ELs) to be assigned to specialist-teachers, such as ESL and bilingual education teachers (Malsbary \& Applegate, 2016).

For this reason, we focus in this paper on ESL teachers in US elementary schools and the ways in which they shape their work in order to realize their vision of providing ELs with optimal support. Our rationale for selecting these teachers is two-fold. First, the diversity of ELs - a heterogeneous group by nationality, language background, race and ethnicity, age of arrival, and previous school experience — creates a need for improvisation. Second, ESL teaching is not a part of the basic "grammar of schooling" (Tyack \& Tobin, 1994, p. 454), with its standardized institutional practices in dividing time and space, classifying students and allocating them to grade-level classrooms, and organizing content knowledge into subject areas such as math and science. ESL teachers, therefore, have to define and organize their work to a much greater extent than grade-level and content-area teachers, whose work is more specified in terms of subject area(s) and related content standards. In this paper, drawing particularly on the nascent theory of job crafting in organizational studies, we examine the specific ways in which a group of ESL teachers acted agentively by redesigning their work through job crafting.

In the following sections, we first provide a concise description of some of the key features of K-12 ESL teaching in the United States, together with a review of relevant research on ESL teachers' work practices. We then present an exposition of job crafting theory, augmented by ideas from research on teacher agency. Finally, we report findings from a qualitative case study, illustrating how a group of ESL teachers shaped their work within the context of their schools.

\section{ESL Teachers and Teaching}

ELs are the fastest growing segment of the U.S. K-12 student population, totaling approximately 5 million and constituting nearly $10 \%$ of the total student population (Ruiz Soto, Hooker, \& Batalova, 2015). All U.S. K-12 schools are legally required to provide additional language support for students designated as "limited English-proficient," in compliance with the US Supreme Court decision - the 1974 case of Lau V. Nichols. However, because the Lau decision did not specify the type of support or take into account the number of designated students 
involved, various realizations of language support are allowed, including ESL services, bilingual education, and sheltered instruction. Many districts and schools have responded to this requirement by adding some form of ESL services to their existing organization (Kandel \& Parrado, 2006). ESL services are usually implemented through 'pullout,' 'push-in,' or coteaching models. In a full pullout model, ESL specialists provide ELs with explicit instruction in English language development for a designated amount of time each week (Ovando \& Combs, 2012), whereas push-in and co-teaching models require ESL and grade-level teachers to collaborate in their planning and instruction.

\section{Research on the Work of K-12 ESL Teachers}

Previous research on K-12 ESL teachers' work in English-speaking countries across the globe, including the United States, the United Kingdom, and Canada, has reported considerable variability in ESL teachers' practices according to the local definition of what constitutes their work (e.g., Hopkins, Lowsenhaupt, \& Sweet, 2015; Leung, 2016). This body of research, comprising mostly descriptive studies, has also revealed the challenges and difficulties that ESL teachers face in the current era of accountability (e.g., Harper \& de Jong, 2009; Miller, 2011; Trickett et al., 2012). For example, Harper, de Jong, and Platt (2008), in their study of Florida ESL teachers, have shown how the enforcement of accountability mechanisms and measures has led to the devaluation of ESL teachers' specialized knowledge and skills by requiring them to perform additional, non-ESL instructional responsibilities. Similarly, in Canada, Bascia \& Jacka (2001) reported that elementary ESL teachers were required to act as classroom aides to gradelevel teachers and were expected to perform non-ESL teaching tasks (e.g., acting as substitute teachers). Another example of such devaluation was reported by English \& Varghese (2010) in relation to an ESL-facilitator model adopted by a school district in Washington State. There, due to the district's interpretation of ESL expertise as comprising only a set of strategies for teaching ELs, each ESL teacher was given the impossible task of 'facilitating' - providing ESL-support across grade-levels- as many as 40 grade-level teachers at two elementary school sites. This kind of marginalization of ESL has been attributed, in addition, to various other factors, including the widespread perception of ESL as not constituting an academic discipline (e.g., Harper, de Jong, and Platt, 2008; Leung, 2016) and of insufficient understanding of ESL teachers' roles and responsibilities on the part of grade-level teachers (Hamann \& Reeves, 2013). In practice, this marginalization manifests itself in different ways, from their not being afforded the same status or authority as other teachers with respect to curriculum (e.g., Arkoudis, 2006; Creese, 2005), to being socially and physically marginalized in the assignment of classrooms (Liggett, 2010), to feeling ignored and invisible in the school (Trickett et al., 2012).

Conversely, however, Trickett and his colleagues (2012), in their study of 16 secondary ESL teachers in a US Midwestern metropolis, found that, despite the marginalized status assigned to ELs and to themselves in their schools, the teachers devised ways to counteract the marginalization that they and their students experienced. When asked about their work lives, they primarily discussed activities in which they engaged outside rather than inside the 
classroom. While they noted the challenge of teaching students with widely varying levels of English proficiency and of previous schooling, what was most salient in their responses was the advocacy roles they played, which were outside their job description. These roles included: "providing protective advocacy" (p. 290) for ELs, when interacting with content-area teachercolleagues (e.g., with respect to grading practices or cultural misunderstandings of ELs' actions); developing relationships with key school administrators to influence the class placement of ELs; and setting up programs in their own time for ELs' parents (e.g., providing information about community resources related to immigration and mental health). Other reported advocacy roles involved "discussions with students about how to negotiate the broader school culture" and helping them with college scholarship opportunities (p. 278).

The findings reported by Trickett and his colleagues are particularly interesting in the light of what Johnson (2016) calls "three fundamental questions that constitute the core of language teacher education," which can be equally applied to the TESOL context: What is it that [ESL] teachers need to know? What is it that [ESL] teachers need to be able to do? And how are these matters best learned? (p. 121). In addressing the first two questions in TESOL teacher education, a praxis approach is called for. That is to say, the knowledge-base of TESOL teacher education should consist not only of theoretical knowledge, including second-language acquisition, assessment, and teaching methods, but also of more practical knowledge of the range of actual work practices and roles performed by ESL teachers. In this context, the current paper aims to contribute to the body of descriptive studies of ESL teachers' work reviewed above, particularly in relation to uncovering the ways in which they proactively shape their work in order to achieve their educational goals. In so doing, it also aims to contribute to building the knowledge-base of TESOL teacher education.

\section{Theoretical Framework}

While teacher agency may manifest in wide-ranging ways, we focus here on specifically 'job crafting' aspects of teacher agency: how ESL teachers define and redesign their work in particular institutional settings by acting agentively to align their practices with their conceptualization of ESL teachers' work. Using teacher agency as a superordinate concept to theorize the phenomenon of teachers' agentive actions, we draw on job crafting theory as an analytic heuristic to identify and describe the kinds of actions taken by teachers. In this section, we briefly describe how we conceptualize teacher agency (rather than an exhaustive review) and then present job crafting theory.

\section{Teacher agency}

Three main conceptualizations of teacher agency can be found in the current literature: agency as variable, agency as capacity, and agency as phenomenon/doing (Priestley, Biesta, \& Robinson, 2015). We adopt the agency-as-phenomenon/doing conceptualization for the following reasons. First, we believe that it is necessary to take account of social contributions to the development of agency, which are ignored if agency is treated as an innate variable. Second, the agency-as- 
capacity conceptualization, as defined as the teacher's "socioculturally mediated capacity to act" (Ahearn, 2001, p. 112), does acknowledge that agency is subject to contextual mediation and emphasizes the interaction between the personal and the social. However, the emphasis nevertheless remains on 'capacity.' By contrast, in our view, teacher agency is something "achieved and not merely ... a capacity or possession of the individual" (Priestley Edwards, Priestley, \& Miller, K., 2012, p. 197); it is an emergent phenomenon that occurs in an "actorsituation transaction" (Biesta, Priestely, \& Robinson, 2015, p. 625). That is to say that teachers always act "by means of their environment rather than simply in their environment" (emphasis added) and that "the achievement of agency will always result from the interplay of individual efforts, available resources and contextual and structural factors, as they come together in particular and, in a sense, always unique situations" (Biesta \& Tedder, 2007, p. 137). Thus, whether and how teachers succeed in acting agentively depends not only on their individual experiences, skills, and dispositions, but also on the kinds of ecological conditions that they encounter in the different contexts of classroom, school or community, and even in microcontexts within them.

Accumulating evidence has provided support for the agency-as-phenomenon/doing conceptualization; both teachers' current environments and their past experiences contribute to shaping, constraining, and enabling teacher agency (e.g., Lipponen \& Kumpulainen, 2011; Varghese \& Stritikus, 2005). However, previous research on this topic has also pointed to a wide range of ways in which teacher agency manifests itself, depending on the exigencies of particular situations and the individuals involved. It may take the form of resistance to or compliance with educational structures in ways that meet professional needs (Achinstein \& Ogawa, 2006; Quinn \& Carl, 2015) or, under imposed curricular reforms, developing alternative forms of effective pedagogical practices to counter the imposed curricular change (Ollerhead, 2010; Molina, 2017; Tao \& Gao, 2017). In this paper, while being cognizant of the multiple ways in which teachers can exercise agency, we specifically focus on the agentive actions taken by teachers in order to align their practices with their beliefs about what constitutes ESL teachers' work.

\section{Job crafting theory}

While the agency-as-phenomenon/doing conceptualization, as described above, guides our inquiry in understanding teachers' agentive actions, we use job crafting theory (Wrzesniewskum \& Dutton, 2001) as our analytical framework to identify and analyze the various agentive actions that teachers take in order to achieve their goals. The concept of job crafting was proposed in organizational studies to draw attention to job redesign by individual workers. Originally conceptualized as an individual phenomenon, it is now regarded as both individual and collective; in this respect, Leana, Applebaum, and Shevchuk (2009) introduced the concept of "collaborative crafting" (p. 1169) to describe the group job-crafting efforts of early childcare teachers in the United States. Thus, job crafting refers to the various ways in which individuals or groups of individuals define and redefine the boundaries of their jobs, as they act in the light 
of their professional commitments and goals rather than simply in response to official directives. Job crafting creates "opportunities for employees to experience the meaning of their work differently by aligning the job with their values, motivations, and beliefs" (Wrzesniewskum \& Dutton, 2001, p. 289). According to Berg, Dutton, and Wresniewski (2013), the process of job crafting "puts the proactive, agentive behaviors of employees at center-stage, conceptualizing and empirically exploring the creative and motivational bases of employees altering their jobs to improve their experience of work" (p. 282, emphasis ours).

In job crafting, there are three forms of crafting in which individuals engage: task, relational, and role. ${ }^{2}$ While the three overlap in practice, they can be analytically distinguished. Task crafting relates to the responsibilities that a particular job entails, many of which are dictated in either contract or policy documents. It involves the physical or temporal boundaries around the particular tasks that individuals consider to be their job and consists of "adding or dropping tasks, adjusting the time or effort spent on various tasks, and redesigning aspects of tasks (Berg et al., 2013, p. 283). A teacher may, for example, elect to spend time learning a new classroom technology to fulfill her/his passion for instructional technology. Relational crafting entails re-marking the relational boundaries that define the interpersonal interactions involved in the performance of work (e.g., spending more time with preferred individuals, reducing contact with others). Teachers may elect to support each other professionally, creating a culture of collaboration in their school, or they may elect to work in isolation. Finally, at a more abstract level, role crafting refers to the understanding a person has of what it means to have a particular job; this involves setting conceptual boundaries that ascribe meaning or purpose to the tasks and relationships that comprise their job. For instance, for one individual, being a school principal may prioritize the competent running of the school and aiming for students' high academic achievement, while for another, it may give equal precedence to the additional commitment of promoting students' engagement with learning and ensuring that equitable practices permeate the school culture. Role crafting therefore has a bearing on the other two domains, in that a person's concept of a job is likely to entail the valuing of some tasks and/or relationships more than others. Thus, it should be clear that the three forms of job crafting are not mutually exclusive, and that job crafters may engage in any combination of the three.

In sum, in this paper we understand teacher agency as involving agentive actions that are situated both contextually and temporally and are intimately connected to teachers' definitions of what constitutes their work as well as their espoused beliefs and values about education. We analyze the manifestation of teacher agency through the lens of job crafting. We focus on the ways in which teachers attempt to bring their practice into better alignment with their beliefs, values, and goals by changing the parameters of their work. Our guiding questions are: (a). How did ESL teachers act agentively through job crafting to bring their practice into greater alignment with their conceptualizations of what constitutes ESL teachers' work? (b). What factors allowed for or hindered their job crafting? 


\section{Method}

We conducted a qualitative case study of 34 ESL teachers (30 female and 4 male) to learn about ESL teaching practices. These teachers worked in 22 elementary schools across the five school districts that served a US Midwestern metropolis, which had experienced 100-180\% increase in the number of ELs in the previous decade. The ELs, who constituted about $10 \%$ of the student population at the time of the study, included large numbers of Spanish and Somali-speakers and smaller numbers of speakers of other languages. These five school districts included a large urban district, (City District), ${ }^{3}$ which had many low-performing schools, one adjacent mediumsized urban district (Oakville District), and three smaller, relatively well-funded suburban districts (Winchester, Huntsville, Arcadia). Except for some schools in the suburban districts, most of those in which the participant-teachers worked were located in poor neighborhoods, where, according to the state's published records, over 50 percent of students were classified as "economically disadvantaged." For all the districts, ESL pullout, in which ELs are pulled out from the grade-level class to receive separate language-focused ESL instruction, was the default model, although it was only enforced in City District. Other districts allowed more flexibility in the choice of ESL instructional models at the school level. ESL teachers provide ELs with explicit instruction in English language development for a designated amount of time each week (Ovando \& Combs, 2012).

\section{ESL teacher-participants}

With the help of the district administrative officers, we used email to contact ESL teachers in elementary schools across the five districts and subsequently also used a "snowball" approach (Patton, 2001). Most of the teachers interviewed had taught various subjects, such as elementary education, foreign-languages, and science, after obtaining their initial teaching certification, but had later obtained an add-on ESL certification through university-based course- work and by passing the state praxis test. A small number had worked as ESL paraprofessionals or had taught EFL overseas prior to becoming certified through traditional teacher preparation programs. The participant group was thus diverse, differing with respect to background, professional experience, and current ESL teaching arrangements and, in this way, constituted a type of "maximum variation" sampling (Patton, 2001).

However, apart from two cases, common across the sample was the limited contact time that the ESL teachers had with their ELs, unlike that of grade-level and bilingual education teachers. For instance, bilingual education teachers in elementary schools typically teach the same students a range of subjects using some combination of two languages, spending a large part of each day with their students. By comparison, the amount of contact time that ESL teachers in English-only schools spend with their ELs is limited-typically 30-45 minutes per day for each student. This was largely the case with the ESL teachers in the current sample, who reported that they taught 7-8 such periods of ESL per day in addition to carrying out other school duties. 


\section{Data sources and analytical procedures}

The primary sources of data were an in-depth semi-structured interviews conducted with each participant teacher and, in a few cases, with pairs upon their request, using a guide created for the project, with each interview lasting over one hour on average. We also collected classroom artifacts from the teachers, including lesson plans, teaching schedules, and classroom materials, as well as school- and district-related information. Where permitted, we also observed and wrote observational notes about the ESL teachers' classes and some of the grade-level classes that contained a high number of ELs. We treated the interviews with teachers as interactive events, regarding participants as informative commentators on the institutional worlds that they inhabited. In the interviews, the teachers were first asked to describe their career trajectories, including their pathways to ESL teaching, their training, and the jobs they had had, and then they were prompted to explain in detail their day-to-day practices in their current schools. They were also asked to discuss their pedagogical visions, the affordances and constraints of their school contexts, their school's administrative structures, their relationships with colleagues, the tasks for which they made themselves responsible, and the classroom arrangements that they had negotiated. To understand how ESL services were organized at the district level, we also conducted semi-structured interviews with each of the five districts' ESL coordinators as supplementary sources of data.

While all the participating teachers we interviewed acted agentively in various ways, in this study, because of our interest in the work practices of ESL teachers who proactively crafted their jobs by changing the parameters of their work beyond what was required of them, we selected for analysis the transcripts of twenty-one teachers. Drawing on job crafting theory as an analytic heuristic, we examined the interview transcripts of job crafters and identified their 'accounts' of their job-crafting efforts, which we defined as their proactive changes to the formal task, relational, or role boundaries of their jobs and the perceptions and experiences that they associated with making such changes (Berg, Dutton, \& Wrzeniewski, 2013).

The analysis was conducted by the research team, consisting of two research assistants and the authors. Following the procedures of Berg, Wrzeniewski, and Dutton (2010), we first extracted and then coded quotes in which the teachers described their job-crafting efforts and the perceptions and experiences that they associated with such efforts. Both quotes and coding were double checked and discussed by at least two team-members until agreement was reached (see Table 1 for coding examples). We then organized these accounts in a spreadsheet according to the three forms of crafting (task, relational, role), and also included information about the outcomes, motives, facilitators - or inhibitors - that influenced their crafting. In the last phase, in order to establish general patterns and themes, we created a table that clustered the teachers who engaged in job crafting into three groups according to whether they engaged in individual or collaborative crafting or a combination of both, and within each group according to what forms of crafting occurred-role, task, relational. Additionally, for each teacher-group, we further considered the relationship between institutional factors, individual attributes, and the forms of job crafting that occurred, and wrote extensive analytic memos. We also cross-referenced these 
analyses with other types of data such as classroom observational notes, classroom artifacts, and school information.

\section{Table 1}

\section{Coding Examples: Forms of Job Crafting}

\begin{tabular}{ll}
\hline Form & Quotes \\
Role crafting & I play the role of interpreter at parent-teacher conferences. I speak \\
-Creating new roles & Spanish fluently ... [Although I don't speak Somali] But I kind of \\
& feel like the cultural connection even with my Somali students, like \\
& if I know there's a parent teacher conference, or the student is \\
& struggling, I want to be in the meeting to be talking with the family \\
& as well. Just to kind of see or look for cultural issues that come up \\
& to help the classroom teacher be a bit more aware of that. Not that \\
& they're not. I still think because of some of my ESL training I am \\
& more attuned to cultural differences, to try to help teachers see that \\
& that this kid is not special ED, but just that there's cultural things that \\
& happen there (Mr. Weaver, Oakville District)
\end{tabular}

Task crafting

- altering the scope or nature of tasks
I work during their reading time in one class and writing time in two other classes ... However, there is a class that I've been doing writing with and through our assessments have found that they're doing really well in writing. So the teacher and I have sat down and tried to reevaluate what's a better use of my time because if they're doing so well in writing. Then maybe I need to work with them when they're reading. So, I've started pulling the kids and working with them on some reading comprehension. (Ms. Wright, Oakville District)

Umm we have a program set up here where we [ESL teachers] can go observe other classrooms. We have some new [grade-level] teachers this year. I've taught two or three lessons in each of their rooms because they wanted support [in teaching ELs]. Or I'll go in and work with a couple of our [EL] kids with the teacher, so that she can see kind of the things that I'm doing and the strategies that I'm using. (Ms. McDonald, City District)

Note. Following the procedures of Berg, Wrzeniewski, and Dutton (2010), we used three main codes for forms of job crafting: Role crafting, task crafting, and relational crafting. Each major 
code consisted of two sub-codes: role crafting (creating new roles; redefining perception of the type or nature of tasks or relationships involved in one's job); task crafting (taking on additional tasks; altering the scope or nature of tasks); and relational crafting (creating additional relationships; altering the extent or nature of relationships).

\section{Findings}

We report our findings in relation to the three teacher-groups that we identified in terms of the nature and type of job crafting in which they engaged: individual, collaborative, and individual and collaborative. For the majority of teachers across the groups, the primary motivation for job crafting was related to their envisioned roles as advocates for their students and families. Following Dubets and de Jong (2011) and Oliveira and Athanases (2007), we adopted the characterization of teacher advocacy as including non-political activities and as involving both within-the-classroom and beyond-the-classroom advocacy. In this paper, we define 'advocacy' as acting agentively on behalf of ELs and/or their families to ensure that they were treated equitably and had access to needed resources. It should be noted that our accounts in this section are largely descriptive, and when we use the term 'job crafting,' we are simultaneously connoting teachers' agentive actions, as our focus is on job-crafting aspects of teacher agency.

\section{Individual crafting: Acting as advocates and cultural mediators}

Five out of the twenty-one teachers engaged in individual job crafting. All five adopted a pullout ESL model because it was either mandatory or the most feasible option in their school context. As a consequence, their job crafting occurred primarily beyond the classroom. They were all veteran ESL teachers who were fluent English-Spanish bilinguals, and they considered multiple advocacy roles to be an important aspect of ESL teachers' work. Their role crafting (creating advocate roles) led to both task and relational crating. For example, a new role, that of acting as an ESL expert for grade-level teachers, led them to model ESL strategies for the teachers in their classrooms; this meant adding a new task to their word load (task crafting) and altering the extent and nature of relationships with their grade-level teacher-colleagues (relational crafting).

Perhaps because all five were well-respected, experienced teachers, they were able to create the role of ESL expert in the school, in which role they provided ESL support to their grade-level teacher-colleagues. For example, in Winchester District, Ms. Lopez, a native of Puerto Rico, created the role of "EL coach" for herself, visiting different grade-level meetings, one grade level per month, in order to offer her grade-level colleagues concrete guidance in teaching the specific ELs in their care.

These five teachers, who had extensive cultural immersion experiences, also engaged in other kinds of job crafting, intentionally reaching out to parents in a range of ways. Four of the five, whose home language was Spanish, had experienced being immigrants in the United States, and the other had served as a missionary in South America. Because of their personal experiences, they believed high parental involvement in their children's education to be critical for their success and so, in order to facilitate this process, they took on the role of cultural mediator for ELs and their parents. 
For example, Mr. Weaver in inner-city Oakville District voluntarily assisted his grade-level teacher-colleagues in their teacher-parent conferences with ELs' parents, which entailed both task and relational crafting (assisting in conferences; interacting with a teacher-colleague and parents as an interpreter/cultural mediator). Although he was not fluent in all the parents' firstlanguages, he felt that he was more "attuned to cultural differences" than his grade-level colleagues because of his prolonged cultural immersion as a missionary in South America and his hard-earned fluency in Spanish. This, he believed, helped him to connect with immigrant parents more easily than his colleagues. He also wrote his report cards in Spanish for his Spanish-speaking ELs so that their parents could read them, while also recommending to his ELs and their parents that they continue to develop their home languages.

As part of their outreach, these teachers also organized workshops for ELs' parents on the school premises, thereby also engaging in task crafting (workshops) and relational crafting (expanding their work parameter to include parents). Ms. Lopez was a case in point. While recognizing that district-level parental orientation events provided basic information about the US education system and the district's schools, she felt that her ELs' parents, who were predominantly Spanish-speaking with low first-language literacy and low socio-economic backgrounds, needed more interactive sessions in which they had opportunities to ask questions, voice their concerns, and gain practical strategies to help their children. Ms. Lopez considered that helping both her ELs and their parents to transition to the new culture and to school practices was an important component of ESL teachers' work.

A different approach to job crafting was taken by Ms. Ortega in City District, a native of Paraguay, who explicitly positioned her ELs' parents as equal partners in helping their children succeed in school:

I really think they [ELs' parents] are very committed to education. . . .so many of our families [parents] didn't even finish high school, but it doesn't mean that they didn't value education. No. Because they don't know how to speak English doesn't mean that they don't value learning a language. So, I can always tell them I need help, you know, with something, and I pick up the phone and I say, "I'm really worried, Lucas is not reading. What's happening? I need your help." . . . their parents are very willing to help the classroom teachers. . . .but I think WE have to make that happen. . . .YOU have to say, "You're important. I need your help. Can you give me a hand?" (relational crafting: altering the extent or nature of relationships)

Ms. Ortega reported that, through these personal phone calls in Spanish (or in other languages with an interpreter's help) and her ongoing collaboration with her ELs' parents, she stressed their collaborative relationship ("we" herself and the parents), making clear that they mattered greatly in enhancing their children's educational experiences.

In sum, these teachers worked in schools in which there was little room for maneuver in attempting to change instructional configurations due to the district's enforcement of an ESL 
pullout model and the fact that ESL being scheduled after other subjects were scheduled. Consequently, their job-crafting efforts centered primarily on beyond-the-classroom activities, in which they played multiple advocate roles such as providing support for grade-level teachercolleagues, involving parents as equal partners in the education of ELs, and engaging in parental outreach.

\section{Collaborative crafting: ESL teachers' joining forces}

Six ESL teachers crafted their jobs collaboratively by working in pairs (Leana et al, 2009). All three pairs worked in schools with a similar demographic, namely that of an older, low-income neighborhood that served mainly Anglo and African American students from working-class families as well as Latino-origin EL newcomers. As was the case with the first group, this group, consisting of experienced ESL teachers, also considered advocacy to be central to their work. In each pair one of the teachers was a fluent English-Spanish bilingual, and the other developed Spanish proficiency sufficient to communicate with ELs and their parents by undertaking additional study of the language on their own. Taken together, these six teachers engaged in job crafting through parental outreach, acting as ESL expert, and/or the reconfiguration of their ESL instruction.

Akin to the first group of teachers, these six also engaged in role crafting by establishing multiple roles in advocating for ELs and their families beyond the classroom. They acted as ESL experts (role crafting), providing ESL support for their teacher-colleagues individually and/or at faculty meetings when EL-related issues were discussed (task and relational crafting). They were also active in parental outreach in a variety of ways. For example, Ms. King and Ms. McDonald in City District regularly visited ELs' families to ensure that their ELs had stable homes and that their daily needs were met (task crafting; expanding the work parameter to include parents). They performed social-worker-like tasks, acting as mediators between the families and social services and helping them locate needed resources (e.g., contacting the Children's Services for them). The Jones-Novak pair also in City District performed similar parental outreach, drawing on Ms. Jones' network of contacts in the community after long-years of work as a community activist. In Huntsville District, another ESL pair, Ms. Evans and Ms. Rosenthal, organized parent-teacher conferences in the large high-rise apartment complexes where many of their Somali and Latino families lived. The choice of these venues dramatically boosted the level of parental participation, particularly that of Somali parents.

Two City District pairs also crafted their jobs by changing their ESL instructional configurations. Instead of the traditional ESL pullout model with each teacher taking responsibility for teaching ELs at particular grade-levels, in each case they decided to co-teach all ELs in their school, a little over 100 ELs at each school. They considered co-teaching as a form of advocacy, as they believed that their overseeing ELs' academic and social development over a longer period of time would benefit their students. They also believed co-teaching would allow them to teach more effectively. For instance, Ms. King explained that she no longer felt "DRAINED," as she could pool instructional ideas, assess lessons, and improve upon them 
together with her colleague. What made the co-teaching arrangement possible was the institutional support provided by their principals through prioritizing ESL in the scheduling of the school timetable. This allowed the teachers to pull ELs out of their regular classes on a grade-level basis. The two teacher-pairs used a study-center approach in their ESL pullout. At each grade level, they created centers (e.g., reading, writing) in which all ELs were taught in parallel by the four members of the ESL staff, the two ESL teachers and two bilingual aides (one Somali-speaking; the other Spanish-speaking). Co-teaching all ELs in the school with three others in the same classroom required role crafting to make teaching a distributed responsibility, which led to task crafting (e.g., creating study-centers) and relational crafting by expanding relational boundaries to include an ESL teacher-colleague and bilingual aides as teaching partners.

\section{Individual and collaborative crafting: Negotiating varied micro-contexts of teaching}

Ten teachers, some experienced and some relatively novice, engaged in both individual and collaborative crafting by using various combinations of ESL pullout, push-in, and co-teaching. Eight of the ten were self-identified EL advocates, which they regarded as integral to an ESL teacher's work. Similar to the second group, they considered both the choice of an appropriate instructional model for particular ELs, acting as an ESL expert, and engaging in parental outreach as forms of advocacy. This group primarily described their job crafting as involving instructional reconfiguration, which necessitated role crafting and this, in turn, led to task crafting by creating additional tasks (e.g., negotiating to implement ESL push-in) as well as relational crafting by expanding their relational parameter of work to include grade-level teachers. Nine of the ten worked in school districts that were shifting from an ESL pullout to an inclusion model, in which ELs studied in their grade-level classrooms where they were provided with linguistic scaffolding by ESL teachers. While in theory, in these districts, ESL teachers had the flexibility of choosing a combination of ESL instructional models, in practice, two factors influenced whether this structural flexibility could be taken advantage of. The first was how ESL instruction was scheduled in the school's timetable, and the second was the extent to which the individual grade-level teachers concerned were willing to experiment with ways of sharing their responsibilities. The former determined instances of possible collaboration with grade-level teachers. Despite the districts' encouragement to switch to an inclusion model and the principals' supportive attitudes towards it, in practice, little attempt was made to accommodate this transition in the timetable. The second factor was preparatory work, relational crafting, that was required to implement either push-in or co-teaching. For example, Ms. White in Huntsville District explained as follows:

I tried having conversations with different teachers to see what kind of feeling they had for it, and at some point, somebody said, "You know, I'm wondering if . . . that's [inclusion is] the best way to serve ELs." I said, "Well, what do you think about trying that?" So, we sort of just had the conversations first, decided that maybe we would jump into it and try it, and it worked out very well and partly because we're able to 
communicate very well, the teacher and I. It's all about you have to be intensely collaborative for it to really work the way it's supposed to be so you have to find somebody you can do that with.

Due to these two reasons as well as others (e.g., pullout model more suitable for low Englishproficient ELs), the majority of teachers reported using a combination of pullout, push-in, and/or co-teaching. ESL push-in typically involved the ESL teacher's taking on a specific range of responsibilities for the EL students in the grade-level class (e.g. guided reading instruction, writing instruction).

There were three reported cases of co-teaching, which the ESL teachers described as engaging in joint planning, instruction, and assessment as equal partners. Ms. Hawkins in Arcadia District is a good example of co-teaching. She used pullout for kindergarten ELs, focusing on reading in small groups. For upper-level ELs, she chose co-teaching in response to her students' frequently voiced expressions of frustration: "we're missing things in [grade-level] class and when can we make that up? and if you want us to do something extra and now we have twice as much to do." Additionally, she found it more empowering to jointly plan lessons, teach, and assess with grade-level teachers. Co-teaching was made logistically feasible at the school because of the 'clustering' in upper-level grades, which involved including special education and EL children together with English-proficient peers in the grade-level class. In these clustered classes, the team of three teachers - grade-level, ESL, and special education — collaboratively taught the class in turn.

A particularly interesting case is Mr. Rios, who experienced both success and failure in his attempts at collaborative crafting. He worked at an inner-city school in City District's poor neighborhood. Mr. Rios was a Spanish-English bilingual, born and raised in a Spanish-speaking enclave in the same state. Because of his own painful memories of being penalized for using Spanish at school, he was determined to support bilingualism/biculturalism among his students and to encourage them to take pride in their heritage. Thus, Mr. Rios expanded the ESL teacher's job to include advocating for ELs and their families. At the kindergarten level, Mr. Rios was able to co-teach with his like-minded colleagues. Together, they enacted a play-based pedagogy, which they believed to be beneficial for kindergartners, and proactively promoted bilingualism and bi-dialectalism among their youngsters (successful role, task, and relational crafting). At the upper-grade levels, however, his proposal to do push-in was rejected by his colleagues, who regarded teaching low-English-proficient ELs as an ESL specialist's responsibility and not their own (unsuccessful role, task, and relational crafting). Frustrated by the constraints on his attempts at agentive action in the upper grades of the school, Mr. Rios found an alternative way of job crafting. He volunteered as a translator for ELs' Latino parents at school as well as at a local library (successful role, task, and relational crafting). In sum, the varied degrees of success of Mr. Rios's attempts at job crafting depended on the extent-or lack - of collegial support available in his particular contexts-for-action (Haneda \& Sherman, 2016). 


\section{Discussion}

Thus far, we have reported our findings with respect to the different types of job crafting undertaken by the participating teachers. In this section, we revisit and discuss these findings in the light of the theoretical framework presented earlier and in relation to the two research questions posed: (a). How did ESL teachers act agentively through job crafting to bring their practice into greater alignment with their conceptualizations of what constitutes ESL teachers' work? (b). What factors allowed for or hindered their job crafting?

In alignment with previous research on language teacher agency (e.g., Molina, 2017; Ollerhead, 2012; Tao \& Gao, 2017; Varghese \& Stritikus, 2005), our findings provide support for the conceptualization of agency as phenomenon/doing (Priestley et al., 2015). That is to say, it was found that agency was achieved as a result of the interplay of the teachers' "individual efforts, available resources, and contextual and structural factors, as they come together in particular and, in a sense, always unique situations" (Biesta \& Tedder, 2007, p. 137). Key factors influencing the achievement of agency through job crafting included teacher attributes on the one hand and contextual and structural factors on the other. The former involved bilingual proficiency, commitment to advocacy, and willingness to negotiate with relevant personnel, including grade-level colleagues. The latter were the different districts' policies with respect to ESL instruction as well as school-level factors, such as the negotiability of the school's timetable and grade-level teachers' willingness to collaborate.

Institutional settings can be considered to be distributed along a continuum from greater to lesser constraint. In the current study, when the institutional constraints were great (e.g., the imposition of a mandatory ESL pullout policy), the majority of the teachers we interviewed chose to engage in job crafting beyond the classroom, performing multiple advocacy roles such as acting as ESL expert for grade-level teachers and helping ELs' parents become involved in the education of their children. These advocacy roles parallel those that were taken up by a group of US secondary ESL teachers in a study by Trickett and colleagues (2012). In the case of the teachers in our study, three personal attributes seem to have influenced the teachers' decisions to engage in beyond-the-classroom job crafting: English-Spanish fluency, perceived welldeveloped cultural sensitivity, and desire to act as cultural mediator-advocates for ELs and their families.

On the other hand, even if there was district-imposed policy, when school principals actively supported ESL teachers' job-crafting initiatives (e.g., prioritizing ESL scheduling in the school's timetable), ESL teachers were able to engage in "collaborative crafting" (Leanna et al., 2009) within the school by reconfiguring the form of ESL instruction itself.

By comparison with the first two groups, the teachers in the third group who worked under less constraining institutional conditions were able to make small, but significant, changes in their schools' instructional organization through more varied forms of job crafting. The majority of these teachers, while choosing to use pullout in some of the grades for which they 
were responsible, in the other grades they recruited grade-level teacher-colleagues as collaborators in the implementation of push-in or co-teaching. To do so successfully, they had to negotiate with the grade-level teacher, which required substantive redrawing of the boundaries of their job parameters.

Finally, as an example of the extent to which the variable micro-contexts-for-action within a school may interact with a teacher's agentive actions, it is worth recalling the case of Mr. Rios. As a consequence of the differential support he received from teacher colleagues and the principal, this teacher's collaborative crafting was successful at one grade level, but unsuccessful at others. Frustrated by the latter, he significantly increased his involvement in outreach to parents.

While favorable institutional circumstances can afford a potentially wider range of job crafting, these in themselves do not ensure that job crafting will ensue, as it is ultimately up to the teachers to take advantage of opportunities for experimentation. This lends support to Biesta and Tedder's (2007, p. 137) assertion regarding agency, that is to say that individuals act "by means of their environment rather than simply in their environment." Put differently, teachers facing similar institutional situations may act differently because of such factors as their evolving goals, the availability of necessary resources, both human and material, and the willingness of key school personnel to negotiate.

Job crafting, then, is a feasible way for teachers to redesign their work so that, while fulfilling institutionally established requirements that leave little space for maneuver, they can nevertheless bring their practices into alignment with their evolving professional goals. It is thus encouraging to be able to report that, in the current study, a relatively large number of the participating teachers engaged in some type of job crafting. However, as noted above, there will always a degree of indeterminacy in the possibility of ESL teacher' success in job crafting, since it must unfold as particular individual teachers act by means of their specific environments, each of which has its own institutional affordances and/or constraints (Biesta \& Tedder, 2007). Thus, the way in which teachers achieve agency can be neither predicted nor prescribed, since specific institutional circumstances give rise to different opportunities for job crafting.

\section{Conclusion}

What these findings bring to the fore is that teaching involves decision-making not only about instructional practices but also about what roles to perform. For ESL teachers, the organization of their work is much less straightforward than it is for grade-level and content-area teachers, since it depends greatly on administrative decisions regarding how ESL services are to be provided. These decisions include the district level policy regarding the form of delivery of ESL instruction as well as principals' decisions about ESL scheduling. Further, the EL students for whom ESL teachers are responsible are diverse in terms of their English proficiency, ethnolinguistic backgrounds, previous schooling experience, and first-language literacy. While grade-level and content-area teachers make decisions within relatively well-established 
parameters, each ESL teacher has to individually negotiate the local affordances and constraints in order to determine the ways in which they can be most effective in supporting ELs.

Much has been written about the wide range of ways in which teachers exercise agency, ranging from their choice of instructional practices (Tao \& Gao, 2017) to the formation of activist groups to instigate change (Quinn \& Carl, 2015). However, because ESL teachers' work does not fit easily within the "grammar of schooling" (Tyack \& Tobin, 1994), a greater variation can be found in the ways in which their work may be locally defined and actualized. This state of affairs makes it necessary for ESL teachers to engage in job crafting in order to realize what they individually consider to be the most feasible and helpful ways of supporting ELs and their families. However, in order to do so, they also need to develop the ability to quickly assess situational demands and negotiate the parameters of their work in order to be most effective in supporting ELs.

Finally, we believe that our findings have important implications for the preparation and professional development of ESL teachers. As Johnson (2016) points out, in planning TESOL teacher education, it is necessary to determine what ESL teachers need to know and what they need to be able to do: "fundamental questions that constitute the core of [TESOL] teacher education" (p. 121). Our findings, along with those of Trickett and his colleagues' (2012), point to the need for an expanded definition of ESL teachers' work to include multiple advocacy roles and ways to enact them through crafting their jobs. We suggest that, in preparing ESL teachers, attention needs to be paid not only to pedagogy but also to the wider scope of their roles as advocates who navigate the micro-politics of school organization. Job crafting theory is a powerful analytical tool that can be used in TESOL teacher-education classes, since it allows one to unpack the relationship between individual teacher attributes, contextual and structural factors, job-crafting options that are feasible in a particular instructional context.

\section{References}

Achinstein, B. \& Ogawa, R. (2011). Change(d) agents: New teachers of color in urban schools. New York, NY: Teachers College Press.

Ahearn, M. (2001). Language and agency. Annual Review of Anthropology, 30, 109-137. doi:10.1146/annurev.anthro.30.1.109

Arkoudis, S. (2006). Negotiating the rough ground between ESL and mainstream teachers. International Journal of Bilingual Education and Bilingualism, 9, 415-433. doi:10.2167/beb337.0

Bascia, N., \& Jacka, N. (2001). Falling in and filling in: ESL teaching in changing times. Journal of Educational Change, 2, 325-346. doi:10.1023/A:101466892517

Berg, J. M., Wrzesniewski, A., \& Dutton, J. E. (2010). Perceiving and responding to challenges in job crafting at different tasks: When proactivity requires adaptivity. Journal of Organizational Behavior, 31, 158-186. doi:10.1002/job.645

Berg, J. M., Dutton, J. E., \& Wrzesniewski, A. (2013). Job crafting and meaningful work. In B. J. Dik, Z. S. Byrne \& M. F. Steger (Eds.), Purpose and meaning in the workplace (pp. 81-104). Washington, DC: American Psychological Association. doi:10.1037/14183-005 
Biesta, G., Priestely, M., \& Robinson, S. (2015). The role of beliefs in teacher agency. Teaching and Teacher Education, 21, 624-640. doi:10.1080/02660830.2007.11661545

Biesta, G., \& Tedder, M. (2007). Agency and learning in the lifecourse: Towards an ecological perspective. Studies in the Education of Adults, 39, 132-149.

doi:10.1080/02660830.2007.11661545

Creese, A. (2005). Teacher collaboration and talk in multilingual classrooms. Clevedon, UK: Multilingual Matters.

Dubetz, N. E., \& de Jong, E. J. (2011). Teacher advocacy in bilingual programs. Bilingual Research Journal, 34, 248-262. doi:10.1080/15235882.2011.623603

English, B. \& Varghese, M. (2010). English language policy through the facilitator model in a monolingual policy context in the United States. In K. Menken \& O. García (Eds.), Negotiating language education policies: Educators as policymakers (pp. 107-122). New York, NY: Routledge.

García, O., \& Kleifgen, J. A. (2010). Educating emergent bilinguals: Policies, programs, and practices. New York, NY: Teachers College Press.

Hamann, E. T., \& Reeves, J. (2013). Interrupting the professional schism that allows less successful educational practices with ELLs to persist. Theory Into Practice, 52, 81-88. doi:10.1080/00405841.2013.770325

Haneda, M., \& Sherman, B. (2016). A job-crafting perspective on teacher agentive action. TESOL Quarterly, 50, 745-754. doi:10.1002/tesq.318

Harper, C., de Jong, E., \& Platt, E. (2008). Marginalizing English as a second language teacher expertise: The exclusionary consequences of No Child Left Behind. Language Policy, 7 , 267-284. doi:10.1007/s10993-008-9102-y

Harper, C. \& de Jong, E. (2009). English teacher expertise: The elephant in the room. Language and Education, 23, 137-151. doi:10.1080/09500780802152788

Hopkins, M., Lowenhaupt, R., Sweet, T. (2015). Organizing English learner instruction in new immigrant destinations: District infrastructure and subject-specific school practices. American Educational Research Journal, 52, 408-439. doi:10.3102/0002831215584780

Kandel, W. A., \& Parrado, E. A. (2006) Hispanic population growth and public school response in two new south destinations. In H. A. Smith \& O. J. Furuseth (Eds.), Latinos in the new south: Transformations of place (pp. 111-134). Burlington, VT: Ashgate.

Janta, B. \& Harte, E. (2013). Education of migrant children: Education responses for the inclusion of migrant children in Europe. Retrieved from http://www.rand.org/content/dam/rand/pubs/research_reports/RR1600/RR1655/RAND_R R1655.pdf

Johnson, K. E. (2016). Language teacher education. In G. Hall (Ed.) The Routledge handbook of English language teaching (pp. 121-134). London, UK: Routledge.

Leana, C., Appelbaum, E., \& Shevchuk, I. (2009). Work process and quality of care in early childhood education: The role of job crafting. Academy of Management Journal, 52, 1169-1192. doi:10.5465/amj.2009.47084651

Leung, C. (2016). English as an additional language - a genealogy of language-in-education policies and reflections on research trajectories, Language and Education, 30, 158-174. doi:10.1080/09500782.2015.1103260 
Liggett, T. (2010). 'A little bit marginalized': the structural marginalization of English language teachers in urban and rural public schools. Teaching Education, 21, 217-232. doi:10.1080/10476211003695514

Lipponen, K. \& Kumpulainen, K. (2011). Acting as accountable authors: Creating interactional spaces for agency work in teacher education. Teaching and Teacher Education, 27, 812819. doi:10.1016/j.tate.2011.01.001

Malsbury, C., \& Applegate, M. (2016). Working downstream: A beginning EL teacher negotiating policy and practice. Language Policy, 15, 27-47. doi:10.1007/s 10993-014-9347-6

Miller, J. (2011). Teachers' work in culturally and linguistically diverse schools. Teachers and Teaching: Theory and Practice, 17, 451-466. doi:10.1080/13540602.2011.580521

Molina, S. (2017). English language teaching in China: Teacher agency in response to curricular innovations. In P.C.L. Ng \& E.F. Boucher-Yip (Eds.), Teacher agency and policy response in English language teaching (pp. 7-25). New York, NY: Routledge.

Oliveira, L. C., \& Athanases, S. Z. (2007). Graduates' reports of advocating for English language learners. Journal of Teacher Education, 58, 202-215. doi:10.1177/0022487107299978

Ollerhead, S. (2010). Teacher agency and policy response in the adult ESL literacy classroom. TESOL Quarterly, 44, 606-618. doi:10.5054/tq.2010.230742_1

Ovando, C. J., \& Combs, M. C. (2012). Bilingual and ESL classrooms: Teaching in multicultural contexts (5th ed.). New York, NY: McGraw-Hill.

Patton, M. Q. (2001). Qualitative research and evaluation methods. Thousand Oaks, CA: Sage.

Priestley, M., Edwards, R., Pirestley, A., \& Miller, K. (2012). Teacher agency in curriculum making: Agents of change and spaces for manoeuvre. Curriculum inquiry, 42, 191-214. doi:10.1111/j.1467-873X.2012.00588.x

Priestley, M, Biesta, G., \& Robinson, S. (2015). Teacher agency: An ecological approach. London, UK: Bloomsbury.

Quinn, R. \& Carl, N. (2015). Teacher activist organizations and the development of professional agency. Teaching and Teacher Education, 21, 745-758. doi:10.1080/13540602.2015.1044331

Ruiz Soto, A., Hooker, S., \& Batalova, J. (2015). States and Districts with the Highest Number and Share of English Language Learners. Washington, DC: Migration Policy Institute. http://www.migrationpolicy.org/research/states-and-districts-highest-number-r -and-share-english-language-learners

Tao, J. \& Gao, X (2017). Teacher agency and identity commitment in curricular reform. Teaching and Teacher Education, 63, 346-355. doi:10.1016/j.tate.2017.01.010

Trickett, E. J., Rukhotskiy, E., Jeong, A., Oberoi, A., Weinstein, T., \& Delgado, Y. (2012). “The kids are terrific: It's the job that's tough": the ELL teacher role in an urban context. Teaching and Teacher Education, 28, 283-292. doi:10.1016/j.tate.2011.10.005

Tyack, D., \& Tobin, W. (1994). The "grammar" of schooling: Why has it been so hard to change? American Educational Research Journal, 31, 453-479. doi:10.2307/1163222 
Varghese, M., \& Stritikus, T. (2005). "Nadie me dijo (Nobody told me)": Language policy negotiation and implications for teacher education. Journal of Teacher Education, 56, 73-87. doi:10.1177/0022487104272709

Wrzesniewski, A., \& Dutton, J. E. (2001). Crafting a job: Revisioning employees as active crafters of their work. Academy of Management Review, 26, 179-201.

doi: $10.2307 / 259118$

\footnotetext{
${ }^{1}$ We consider the term "emergent bilinguals" (Garcia \& Kleifgen, 2010) more appropriate because it emphasizes their multilingual abilities. However, in this paper, we use the term "English learners," that is what is commonly used in the research literature and policy documents.

2 The last term, "role" crafting, is our own, used in place of the original 'cognitive crafting' (Wresniewski \& Dutton, 2001) in order to avoid confusion with the term 'cognition' as employed in educational research.

${ }^{3}$ A pseudonym is used in the case of all five school districts and teachers.
} 